\title{
From the Editor:
}

Slavic Review publishes letters to the editor with educational or research merit. Where the letter concerns a publication in Slavic Review, the author of the publication will be offered an opportunity to respond. Space limitations dictate that comment regarding a book review should be limited to one paragraph; comment on an article should not exceed 750 to 1,000 words. The editor encourages writers to refrain from ad hominem discourse.

\section{D.P.K.}

\section{To the Editor:}

I feel compelled to respond briefly to Jan T. Gross's reply to my remarks (Slavic Review, vol. 61 , no. 3). First, I stand by my statement about his "rather one-sided selection of sources." I tried to be polite by calling it a "rather" one-sided selection, although in fact Gross based his book on selected testimonies and neglected archival research altogether. I feel embarrassed to have to remind him of such basic scholarly duties as doublechecking testimonies against other archival documentation. Gross stated: "No other sources of any significance have been found since the book's publication." Instead of arguing with a "brilliant" documentary film as a source, let me quote at least four archives that he failed to research: Ludwigsburg, Łomża, Białystok, and the Jedwabne parish archives. Had he done his duty, Gross would, for instance, have found that SS-Hauptsturmführer Hermann Schaper did not surface in 2001 but was already identified in the 1960 s by eyewitnesses and by German prosecutorial authorities "with great probability" as the chief suspect of the Jedwabne massacre.

Second, I still maintain that there are numerous factual errors in his book and protest against comparing my brief remarks to pamphlets by extremists in Poland. Lack of space prevented me from mentioning more examples of such errors. Gross failed to defend the statements that I criticized. For instance, he mentioned that municipal authorities of Jedwabne were "constituting themselves" (Neighbors, 72) and he called these authorities "a town council" (73 and 74). Thus he leaves it up to an English reader to guess that these authorities were simply imposed by the Nazis. This is not an "invention" of Bogdan Musial but of Jan T. Gross. As to the presence of the Germans, there is no forensic evidence concerning any of the murderers, but there are testimonies, including those Gross approved of, which indicate that, in addition to at least nine local Nazi gendarmes, four or five German policemen arrived in Jedwabne on that fateful day. It is also these policemen who, according to Gross, met the "town council" (or in fact commissary administrators). It was, by the way, not the custom of the Nazis to "negotiate" with the Poles, as Gross stated, but to give orders. All this, of course, does not mean that I deny that some Poles were perpetrators of the Jedwabne crime.

Third, some authors have a sad habit of replacing serious argument with acerbity, emotional epithets, or personal attacks. It is with regret that I find Gross reacted to my remarks with such terms as "facile" or "unthinking." He will stick to his opinion and I will stick to mine, but let us differ more gently.

WojcIEch RoszKowski Polish Academy of Sciences, Warsaw

To the Editor:

In his review of Larry Wolff, Venice and the Slavs (Slavic Review, vol. 61, no. 2), Lee Congdon writes that Wolff "has a tendency to base his assertions ... on theories he discovered in the work of the late Michel Foucault..... He ends his review by asking "Should not [Wolff] . . . ask himself whether or not the imposition of Foucault's categories on the 
past exposes him to the charge of seeking to dominate discourse in his chosen field." From these comments, one would suppose that Wolff had written a Foucauldian book. Yet in this 362-page text, I was able to find only three references to Foucault totaling about eight sentences. Wolff refers to Foucault in the same way he refers to many other scholars, to Benedict Anderson, for example, or even to Stephen Jay Gould or Rebecca West, when the context of his discussion seems to warrant it. Indeed, in one context in which Wolff refers to Foucault, the efforts of Venetian administrator Paolo Boldu to transform Morlach recruits by disciplining their "inapt" bodies, correcting their posture, and running a "calculated constraint ... slowly through each part of the body" (272), it seems not merely appropriate to refer to Foucault, but almost required. Readers may make their own judgments, but in my view Congdon misrepresents the character of Wolff's effort by plucking a relatively minor element in Wolff's analysis and making it a basic theme of his review.

Gale Stokes Rice University

Professor Congdon replies:

As Professor Stokes says, readers may make their own judgments.

LeE Congdon

James Madison University 